\title{
Sensitivity of runoff to climatic variability in the northern and southern slopes of the Middle Tianshan Mountains, China
}

\author{
ZHANG Feiyun $^{1,2}$, BAI Lei ${ }^{1,2}$, LI Lanhai ${ }^{1 *}$, WANG Quan ${ }^{3}$ \\ ${ }^{1}$ State Key Laboratory of Desert and Oasis Ecology, Xinjiang Institute of Ecology and Geography, Chinese Academy of \\ Sciences, Urumqi 830011, China; \\ ${ }^{2}$ University of Chinese Academy of Sciences, Beijing 100049, China; \\ ${ }^{3}$ Faculty of Agriculture, Shizuoka University, Shizuoka 422-8529, Japan
}

\begin{abstract}
Temperature and precipitation play an important role in the distribution of intra-annual runoff by influencing the timing and contribution of different water sources. In the northern and southern slopes of the Middle Tianshan Mountains in China, the water sources of rivers are similar; however, the proportion and dominance of water sources contributing to runoff are different. Using the Manas River watershed in the northern slope and the Kaidu River watershed in the southern slope of the Middle Tianshan Mountains as case studies, we investigated the changes in annual runoff under climate change. A modified hydrological model was used to simulate runoff in the Kaidu River and Manas River watersheds. The results indicated that runoff was sensitive to precipitation variation in the southern slope and to temperature variation in the northern slope of the Middle Tianshan Mountains. Variations in temperature and precipitation substantially influence annual and seasonal runoff. An increase in temperature did not influence the volume of spring runoff; but it resulted in earlier spring peaks with higher levels of peak flow. Damages caused by spring peak flow from both slopes of the Middle Tianshan Mountains should be given more attention in future studies.
\end{abstract}

Keywords: annual runoff distribution; climatic factors; Kaidu River watershed; Manas River watershed

Citation: ZHANG Feiyun, BAI Lei, LI Lanhai, WANG Quan. 2016. Sensitivity of runoff to climatic variability in the northern and southern slopes of the Middle Tianshan Mountains, China. Journal of Arid Land, 8(5): 681-693. doi: $10.1007 / \mathrm{s} 40333-016-0015-\mathrm{x}$

In arid and semi-arid areas, rivers originate primarily from alpine areas, flow through oases and disappear in deserts. The primary water sources of the runoff in alpine watersheds include water from glacier-melt, seasonal snowmelt, rainfall and groundwater (Yang and Cui, 2005; Xu et al., 2008; Ji and Luo, 2013; Shang et al., 2013). The relative contribution of different water sources depends on precipitation, temperature and timing factors, which change the seasonal distribution of annual runoff (Liu et al., 2015). Precipitation takes place as snowfall in winter and earlier spring and accumulates as snowpack (Zhang et al., 2014). Glacier/snowpack melts as temperature increases in spring, and glacier/snowmelt water charges runoff (Kuusisto, 1984; Kalra et al., 2013; Sun et al., 2015). Water sources from glacier-melt provide stable baseflow for rivers, while snowmelt water often forms peak flows as temperature increases in spring. The snowmelt driven peak and its duration depend on the quantity of accumulated snow during winter and the active

${ }^{*}$ Corresponding author: LI Lanhai (E-mail: lilh@ms.xjb.ac.cn)
Received 2015-12-27; revised 2016-04-28; accepted 2016-05-04
(C) Xinjiang Institute of Ecology and Geography, Chinese Academy of Sciences, Science Press and Springer-Verlag Berlin Heidelberg 2016 
temperature during spring (Zhang et al., 2014). Rainfall directly contributes to runoff through surface runoff and baseflow, albeit with time delays. Heavy summer rainfall often leads to summer peak flow, which depends on rainfall intensity. However, insufficient snowpack in winter and less rainfall in summer often result in spring and summer drought. Therefore, analyzing patterns in the distribution of annual runoff and responses to climatic variation is necessary to provide useful information for managers to effectively allocate and manage water resources for the prevention of unexpected damages, such as flood and drought.

The characteristics of watersheds, such as watershed size, slopes and topography in alpine areas substantially influence the formation of water sources for runoff. The slope of a mountain is one of the most important factors influencing the formation of water sources because windward slopes will receive more air moisture for the formation of precipitation than leeward slopes. The Tianshan Mountains stretch east and west across Xinjiang and separates Xinjiang into the northern and southern regions. More air moisture heads to the northern slope through westerly circulation. The southern (leeward) slope faces the Tarim Basin and is surrounded by Kunlun Mountains and Tianshan Mountains. The closed basin often generates internal circulation of air moisture in the southern slope within the Tarim Basin $(\mathrm{Mu}, 1991)$. As a result, less air moisture feeds to the southern slope. Glacier area and glacier water storage in the northern slope are greater than those of the southern slope in the Middle Tianshan Mountains (MTM; Liu, 1995). Discrepancies in precipitation, glacier area and glacier water storage in the windward and leeward slopes are more obvious in the MTM (Zhao et al., 2011). Annual precipitation is approximately $450 \mathrm{~mm}$ in the northern slope of the MTM and less than $200 \mathrm{~mm}$ in its southern slope (Zhao et al., 2011). Annual glacier-melt water accounts for $14.1 \%$ of the total runoff in the Kaidu River watershed in the southern slope of the MTM (Shi, 2014) and 34.6\% of the total runoff in the Manas River watershed in the northern slope of the MTM (Zhang et al., 2009). Variations in precipitation and glacier melt water in the windward and leeward slopes inevitably result in the changes in hydrological processes (Ran et al., 2006; Li et al., 2009). Therefore, discrepancies in the hydrological processes on the northern and southern slopes require particular attention.

Meteorological and hydrological data availability is crucial for the study of runoff process under climatic variation; however, meteorological and hydrological stations are scarce, and the historical periods of observations in alpine regions are generally short, especially in Xinjiang, northwestern China, where stations are primarily distributed at low altitudes. Data shortages constrain studies on hydrological processes and responses to climatic variation in such regions. Alternatively, modelling is a powerful methodology for analyzing runoff processes in ungauged or insufficiently gauged basins. Various hydrological models have been used in the MTM. The Snow Runoff Model (SRM) was used to test the effect of different temperature indices on snowmelt-driven runoff in the Kaidu River watershed (Zhang et al., 2007; Dou et al., 2011), the Manas River watershed (Chen et al., 2014) and the Künes River watershed (Ma and Cheng, 2003). Yu et al. (2013) and $\mathrm{Li}$ et al. (2014) modified the SRM by using $>0^{\circ} \mathrm{C}$ accumulative temperature to estimate the rate of snowmelt in the Manas River and Kaidu River watersheds. Yu et al. (2011) used different precipitation sources to assess the capability of Soil and Water Assessment Tool (SWAT) to simulate runoff in the Manas River watershed. The Hydrologiska Byrans Vattenbalansavdelning (HVB)-ETH model was used to evaluate the influence of glacier melt water on runoff in the Urumqi River watershed (Yang et al., 2012). The digital filtering method was used to estimate baseflow in the Kaidu River watershed (Li et al., 2012) and in the Tarim River Basin (Fan et al., 2013). The SWAT model considered the effects of glacier melt, snowmelt and rainfall on runoff in the Manas River watershed (Ji and Luo, 2013). Zhang et al. (2016) modified an existing hydrological model developed by system dynamics principles to simulate the effects of daily temperature variation on snowmelt and soil physical state on water infiltration during snowmelt season in the Kaidu River watershed. However, these studies only focused on single river watersheds and rarely compared watersheds on both windward and leeward slopes. Li et al. (2012) statistically compared the impact of meteorological factors on runoff depth in typical watersheds of the northern and southern slopes of the MTM, but the annual runoff pattern controlled by meteorological factors was not taken into consideration. For analyzing patterns of 
runoff contributed by snowmelt water and rainfall on the windward and leeward slopes of the arid zone, we used a modified hydrological model to simulate two typical watersheds located on the windward and leeward slopes of the MTM and to evaluate the sensitivity of the distribution of intra-annual runoff to climate change.

\section{Study area and methods}

\subsection{Study area}

There are 373 rivers in the Tianshan Mountains as determined by the number of mountain passes (Hu, 2004). The MTM ranges from $42^{\circ} 00^{\prime} \mathrm{N}$ to $44^{\circ} 30^{\prime} \mathrm{N}$ and from $82^{\circ} 00^{\prime} \mathrm{E}$ to $86^{\circ} 30^{\prime} \mathrm{E}$. Two of the major rivers are the Kaidu River in the southern MTM and the Manas River in the northern MTM (Fig. 1). The Kaidu River watershed spans from $42^{\circ} 43^{\prime} \mathrm{N}$ to $43^{\circ} 21^{\prime} \mathrm{N}$ and from $82^{\circ} 58^{\prime} \mathrm{E}$ to $86^{\circ} 05^{\prime} \mathrm{E}$. The elevation of runoff generation zone is $>1,400 \mathrm{~m}$ asl, with an average of $3,100 \mathrm{~m}$ asl. The zone covers approximately $18,725 \mathrm{~km}^{2}$; human activity is generally less due to the high elevations. There is only one meteorological station, Bayanbuluk station $(2,458 \mathrm{~m}$ asl), and one hydrological station, Dashankou station $(1,400 \mathrm{~m}$ asl $)$ that have a long-term historical data in the zone. The primary water vapor sources come from the Tibet Plateau on the southern slope (Shi, 2014). However, due to the blocking effects of Kunlun Mountains and Tianshan Mountains, the sources of water vapor on the southern slope often cause internal circulation within the Tarim Basin (Mu, 1991), which is slightly influenced by the sources of water vapor out of the closed basin. Rainfall from June to September accounts for $60 \%-80 \%$ of the total annual precipitation ( $\mathrm{Su}$ et al., 2007). The total glacier area is $445 \mathrm{~km}^{2}$ (Li et al., 2003), accounting for $2.36 \%$ of the Kaidu River watershed. The annual glacier-melt water is $4.82 \times 10^{8} \mathrm{~m}^{3}$, accounting for $14.1 \%$ of the total runoff of the mountain pass (Shi, 2014).

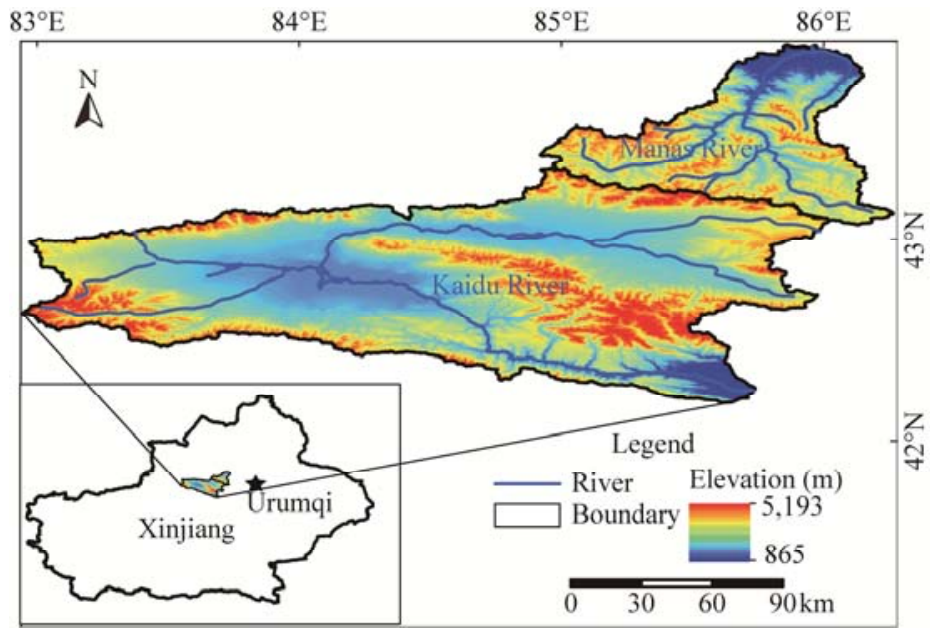

Fig. 1 Location of the Kaidu River and the Manas River watersheds

The Manas River watershed extends from $43^{\circ} 27^{\prime} \mathrm{N}$ to $45^{\circ} 21^{\prime} \mathrm{N}$ and from $85^{\circ} 01^{\prime} \mathrm{E}$ to $86^{\circ} 32^{\prime} \mathrm{E}$. The elevation of runoff generation zone is $>885 \mathrm{~m}$ asl, with an average of $3,018.5 \mathrm{~m}$ asl, and covers an area of $5,156 \mathrm{~km}^{2}$. There is only one meteorological and hydrological station at Kensiwate $(885 \mathrm{~m}$ asl) with a long-term historical data above the mountain pass. The downstream station close to Kensiwate below the mountain pass is Shihezi meteorological station. The primary sources of water vapor come from westerly circulation on the northern slope (Shi, 2014). Due to the MTM, most of the water vapor sources are stopped on the northern slope. Hence, the Manas River watershed receives more sources of water vapor. Rainfall from June to August accounts for $68 \%$ of total annual precipitation (Liu et al., 2009). The annual glacier-melt water is $4.43 \times 10^{8} \mathrm{~m}^{3}$, accounting for $34.6 \%$ of the total runoff in Kensiwate hydrological station (Zhang et al., 2009). 


\subsection{Modification of a system dynamic hydrological model}

This study used a modified hydrological model to simulate runoff in both the southern and northern slopes of the MTM. Li and Simonovic (2002) developed the original model (SDHydro) based on system dynamics principles. The SDHydro model uses five tanks to estimate water dynamics in the vertical direction. The five tanks are used for snow storage, canopy interception storage, surface soil water storage, subsurface soil water storage and groundwater storage. For determining the influence of diel temperature variation on snowmelt processes and the influence of soil physical status on water infiltration, Zhang et al. (2016) modified the SDHydro model. The modifications included replacing daily average temperature with the effective daily $>0{ }^{\circ} \mathrm{C}$ accumulative temperature to estimate snowmelt rate. The influence of the soil's physical status on water infiltration in different soil layers was estimated using soil temperature to judge the physical status of the soil. The modified SDHydro model can more efficiently simulate the change in runoff in the Kaidu River watershed, whose water sources depend on both snowmelt and rainfall. Formulas for calculating the storage in the five tanks are based on the formulas of $\mathrm{Li}$ and Simonovic (2002) and Zhang et al. (2016) and are shown below:

$$
\begin{gathered}
d S 1 / d t=P_{s} c_{1}-\beta \times A T P_{e}, \quad(1) ; \quad d S 2 / d t=R c_{I}-c_{2} T, \quad(2) ; \quad d S 3 / d t=R_{I}-R_{E 1}-R_{F 1}-R_{P 1}, \\
d S 4 / d t=R_{P 1}-R_{E 2}-R_{F 2}-R_{P 2}, \quad(4) ; \quad d S 5 / d t=R_{P 2}-R_{B F} .
\end{gathered}
$$

Where $S 1, S 2, S 3, S 4$ and $S 5(\mathrm{~cm})$ represent the water in snow storage, canopy interception storage, surface soil water storage, subsurface soil water storage and groundwater water storage, respectively. $P_{s}(\mathrm{~cm} / \mathrm{d})$ is snowfall. $c_{1}(\mathrm{~cm} / \mathrm{cm})$ and $c_{2}\left(\mathrm{~cm} /\left({ }^{\circ} \mathrm{C} \cdot \mathrm{d}\right)\right)$ represent the snow water equivalent coefficient and the evaporation coefficient, respectively. $\beta\left(\mathrm{cm} /\left({ }^{\circ} \mathrm{C} \cdot \mathrm{d}\right)\right)$ is the modified degree day factor for estimating snowmelt. $A T P_{e}\left({ }^{\circ} \mathrm{C}\right)$ is active $>0{ }^{\circ} \mathrm{C}$ accumulative temperature. $R_{C I}(\mathrm{~cm} / \mathrm{d})$ is the canopy interception rate. $T\left({ }^{\circ} \mathrm{C}\right)$ represents daily mean temperature. $R_{I}, R_{E 1}, R_{F 1}$ and $R_{P 1}(\mathrm{~cm} / \mathrm{d})$ stand for rates of infiltration, evapotranspiration, interflow and percolation, respectively, in the surface soil water storage, while $R_{E 2}, R_{F 2}$ and $R_{P 2}(\mathrm{~cm} / \mathrm{d})$ are rates of evaporation, interflow and percolation, respectively in subsurface soil layer water storage. $R_{B F}$ $(\mathrm{cm} / \mathrm{d})$ is the baseflow. Detailed information on the SDHydro model and the modification can be referred to in Li and Simonovic (2002) and Zhang et al. (2016). The modified SDHydro model was developed and performed using the STELLA software for simulating runoff in the Kaidu River and Manas River watersheds with daily time steps.

\subsection{Model calibration and simulation}

Runoff in the Kaidu River and Manas River watersheds was simulated using the modified SDHydro model. Due to the large elevational range and the different topographic and geographic conditions in the two watersheds, the contributions of water sources to runoff were different. For efficient simulation of the runoff generated by several water sources, the two watersheds were divided into three sub-catchments: a high elevation zone representing glacier melt water (GMH), a middle elevation zone representing snowmelt water combined with rainfall (SMM), and a low elevation zone consisting of rainfall and snowmelt water (RL). The partition of the three sub-catchments in the Kaidu River watershed was based on the methods of Zhang et al. (2016), while partitioning in the Manas River watershed was based on the methods of Ji and Luo (2013). The northern and southern slopes of the MTM belong to the shady and sunny slopes, respectively. Temperature in the sunny slope is higher than that in the shady slope at the same elevation. Combined with the distribution of temperature and precipitation, the snow line in the southern slope is higher than that in the northern slope (Dou, 2010). Thus, the elevation of GMH and SMM sub-catchments in the Kaidu River watershed should be higher than that in the Manas River watershed. Detailed information on the three sub-catchments in the two watersheds is shown in Table 1.

The only meteorological station for the two watersheds is unable to provide sufficient climate data to represent the three sub-catchments. The linear temperature lapse rate method was used to extrapolate temperature in both watersheds due to the spatial consistency of temperature (Vincent and Gullett, 1999). Temperature lapse rates in sub-catchments RL, SMM and GMH in the Kaidu River and Manas River watersheds were $0.45,0.45$ and $0.65^{\circ} \mathrm{C} / 100 \mathrm{~m}$, respectively. 
Table 1 Detailed information on the three sub-catchments in the Kaidu River and Manas River watersheds

\begin{tabular}{ccccc}
\hline & Sub-catchments & Elevation range $(\mathrm{m})$ & Average elevation $(\mathrm{m})$ & Area $^{\left(\mathrm{km}^{2}\right)}$ \\
\hline Kaidu River & GMH & $>3,950$ & 4,070 & 641.97 \\
watershed & SMM & $2,675-3,950$ & 3,172 & $12,345.40$ \\
& RL & $1,400-2,675$ & 2,464 & $5,737.66$ \\
Manas River & GMH & $>3,500$ & 4,097 & $2,325.99$ \\
watershed & SMM & $2,500-3,500$ & 3,009 & $2,018.67$ \\
& RL & $885-2,500$ & 1,730 & 817.35 \\
\hline
\end{tabular}

Note: GMH, a high elevation zone representing glacier melt water; SMM, a middle elevation zone representing snowmelt water combined with rainfall; RL, a low elevation zone consisting of rainfall and snowmelt water.

Because the meteorological station is situated in the middle stream of sub-catchment SMM in the Kaidu River watershed, precipitation in the watershed can be extrapolated using the precipitation lapse rate. Precipitation lapse rates in the sub-catchments RL, SMM and GMH were 0.0267, 0.0416 and $0.0416 \mathrm{~mm} / 100 \mathrm{~m}$, respectively. In the Manas River watershed, meteorological stations were located at or below the mountain pass of the sub-catchment RL. The location of these stations made accounting for spatial heterogeneity in precipitation difficult. The multiple precipitation lapse rates proposed by Ji and Luo (2013) were used to extrapolate precipitation in different sub-catchments in the Manas River watershed. The effective daily $>0{ }^{\circ} \mathrm{C}$ accumulative temperature is based on the daily mean, maximum and minimum temperatures. The daily mean, maximum and minimum temperatures in both Kensiwate and Shihezi stations were used to extrapolate the corresponding temperature in the Manas River watershed using the temperature lapse rate for calculations of the active $>0{ }^{\circ} \mathrm{C}$ accumulative temperature and soil temperature. For the missing surface soil temperature data, this study used the daily maximum temperature, daily mean temperature and daily minimum temperature as inputs to estimate missing soil temperature data using a feed-forward ANN structure with a back-propagation (BP) algorithm in these two watersheds (Zhang et al., 2016).

Correlation coefficient $\left(R^{2}\right)$, Nash Sutcliff Efficiency (NSE), the ratio of root-mean-square error to the standard deviation of observations (RSR) and percentage bias (PBIAS) were used to evaluate the capability of the modified SDHydro model to simulate runoff in these two watersheds. The general performance ratings for NSE, RSR and PBIAS in monthly steps, as proposed by Moriasi et al. (2007), have been used to evaluate the modified SDHydro model to simulate runoff in the Kaidu River and Manas River watersheds.

Due to the development of dams in the runoff generation area in mountains, runoff data in the last ten years do not reflect natural hydrological processes in the Kaidu River and Manas River watersheds. Hence, climatic data and hydrological data from 1958 to 2005 were used to calibrate and simulate the modified SDHydro model. Daily temperature and precipitation data from 1958 to 2005, provided by the National Climatic Centre of China, the China Meteorological Administration, were used as inputs into the modified hydrological model. Daily runoff data from 1958 to 2005 were provided by Dashankou hydrological station and Kensiwate hydrological station.

\subsection{Scenario design for testing runoff responses to climatic disturbance}

Temperature and precipitation are two important climatic factors influencing runoff through determining contributions from glacier melt water, snowmelt water and rainfall. Shi et al. (2007) suggested that annual mean temperature and annual precipitation will increase by $2{ }^{\circ} \mathrm{C}$ and $19 \%$, respectively in Northwest China due to the doubling of the $\mathrm{CO}_{2}$ concentration. For clarifying the responses of seasonal and annual runoffs to variation in climatic factors, this study examined the following scenarios based on variations in annual mean temperature and annual precipitation.

(1) Daily mean air temperature increases $2{ }^{\circ} \mathrm{C}$ during the entire year $\left(\mathrm{T}_{\mathrm{a}+}\right)$;

(2) Daily mean air temperature increases $2^{\circ} \mathrm{C}$ in spring (March to May) ( $\mathrm{T}_{\mathrm{s}^{+}}$), summer (June to August) ( $\left.\mathrm{T}_{\mathrm{ss}+}\right)$, autumn (September to November) $\left(\mathrm{T}_{\mathrm{aa}+}\right)$ and winter (December to February) $\left(\mathrm{T}_{\mathrm{w}^{+}}\right)$, 
respectively;

(3) Precipitation increases $20 \%$ during the entire year $\left(\mathrm{P}_{\mathrm{a}^{+}}\right)$;

(4) Precipitation as snowfall increases $20 \%\left(\mathrm{P}_{\mathrm{s}^{+}}\right)$, while rainfall does not change. Because the Kaidu River and Manas River watersheds are located at high elevation, the months of October to February were selected to be the solid precipitation period.

Runoff simulated from 1958 to 2005 was considered to be the basic scenario. With climatic disturbance, effective daily $>0^{\circ} \mathrm{C}$ accumulative temperature and soil temperature fluctuated simultaneously.

\section{Results}

\subsection{Model calibrations and validations in the two watersheds}

Zhang et al. (2016) used the modified SDHydro model to simulate high flow, low flow and normal flow in the Kaidu River watershed. The results showed that the modified SDHydro model could efficiently simulate three types of flows. Based on the parameter settings for normal flow, we recalibrated the modified SDHydro model using climatic and runoff data from 1958 to 1981 in the Kaidu River watershed and validated using data from 1982 to 2005 . The simulated runoff in the calibration and validation periods and the observed runoff are shown in Figs. 2a and b. The model was further calibrated using climatic and runoff data from 1958 to 1981 in the Manas River watershed and validated using data from 1982 to 2005. The results are shown in Figs. 2c and d. The results of the four statistical measures are shown in Table 2 to evaluate the performance of the modified SDHydro model in these two watersheds.
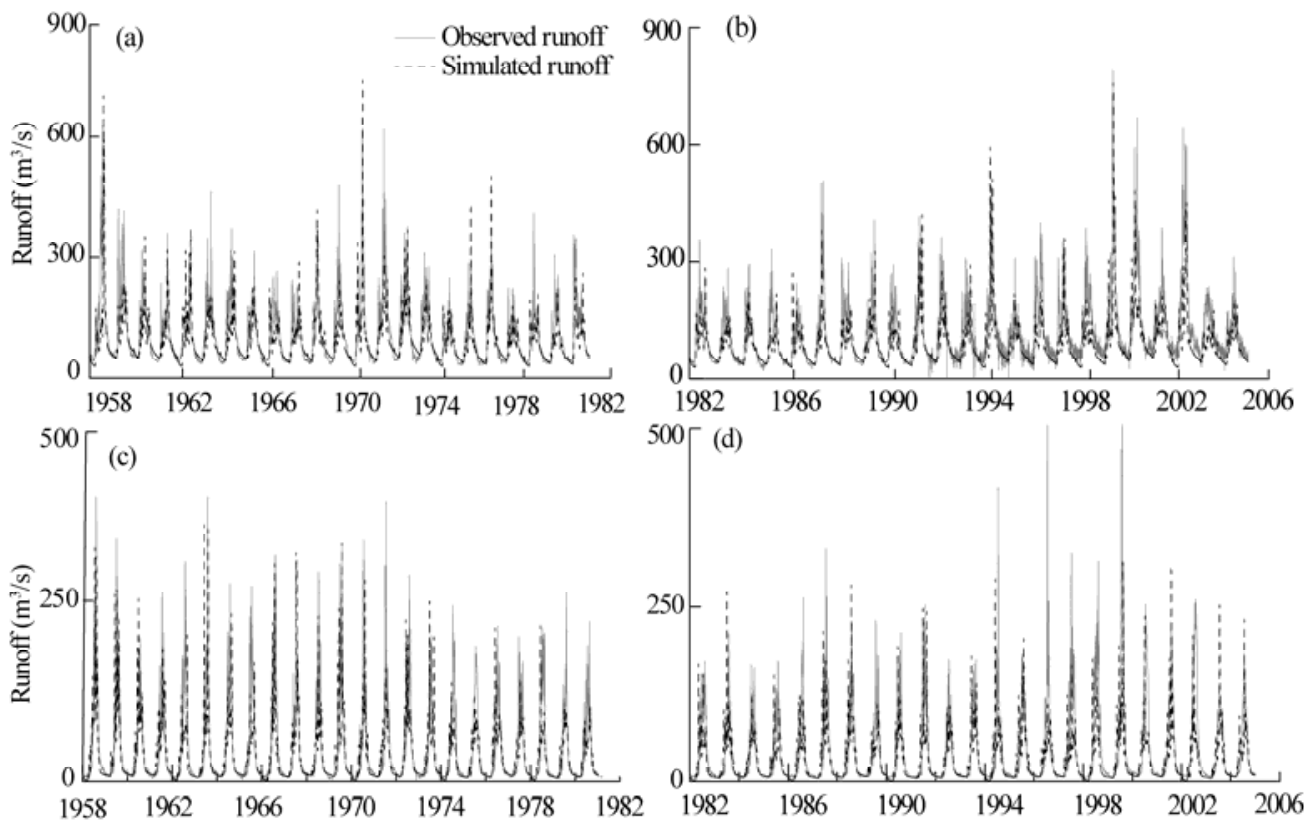

Fig. 2 Observed and simulated runoff in the calibration (a) and validation (b) periods in the Kaidu River watershed and in the calibration (c) and validation (d) periods in the Manas River watershed

Figure 2 indicated that patterns in the simulated runoff were consistent to those observed in the Kaidu River and Manas River watersheds. The runoff in winter as the baseflow was well simulated, while runoff in the summer was relatively poor. Spring runoff was primarily created by snowmelt water in the Kaidu River watershed. This pattern was accurately estimated by the modified SDHydro model. Correlation coefficients and NSE between observed and simulated runoffs in the calibration and validation periods were greater than 0.83 and 0.62 , respectively, in both watersheds (Table 2). RSR and PBIAS were less than 0.62 and 20 in these two watersheds, respectively. According to Moriasi et al. (2007), the performance of NSE and RSR was robust in the calibration and validation periods. The performance of PBIAS was exceptionally robust in the 
calibration and validation periods in the Kaidu River watershed. The performance of NSE, RSR and PBIAS was robust in the calibration period and satisfactory in the validation period in the Manas River watershed. The results indicated that the modified SDHydro model can robustly simulate runoff in both watersheds.

Table 2 Results of the four statistical criteria in the calibration and validation periods in the two watersheds

\begin{tabular}{|c|c|c|c|c|c|c|c|c|}
\hline \multirow{2}{*}{ Watershed } & \multirow{2}{*}{ Period } & \multirow{2}{*}{$R^{2}$} & \multicolumn{2}{|c|}{ NSE } & \multicolumn{2}{|c|}{ RSR } & \multicolumn{2}{|c|}{ PBIAS } \\
\hline & & & Value & Evaluation & Value & Evaluation & Value & Evaluation \\
\hline Kaidu & Calibration & 0.85 & 0.70 & Good & 0.55 & Good & 9.26 & Very good \\
\hline $\begin{array}{c}\text { River } \\
\text { watershed }\end{array}$ & Validation & 0.89 & 0.69 & Good & 0.56 & Good & 18.32 & Satisfactory \\
\hline Manas & Calibration & 0.87 & 0.73 & Good & 0.53 & Good & 11.24 & Good \\
\hline $\begin{array}{c}\text { River } \\
\text { watershed }\end{array}$ & Validation & 0.83 & 0.62 & Satisfactory & 0.62 & Satisfactory & 19.85 & Satisfactory \\
\hline
\end{tabular}

Note: NSE, Nash Sutcliff Efficiency; RSR, the ratio of root-mean-square error to the standard deviation of observations; PBIAS, percentage bias.

\subsection{Responses of runoff to climatic disturbance}

Runoff under designed climatic disturbance scenarios from 1958 to 2005 in the Kaidu River and Manas River watersheds was shown in Fig. 3. The black solid line represents the maximum runoff, while the lower boundary of the grey area stands for the minimum runoff under different climatic disturbances.
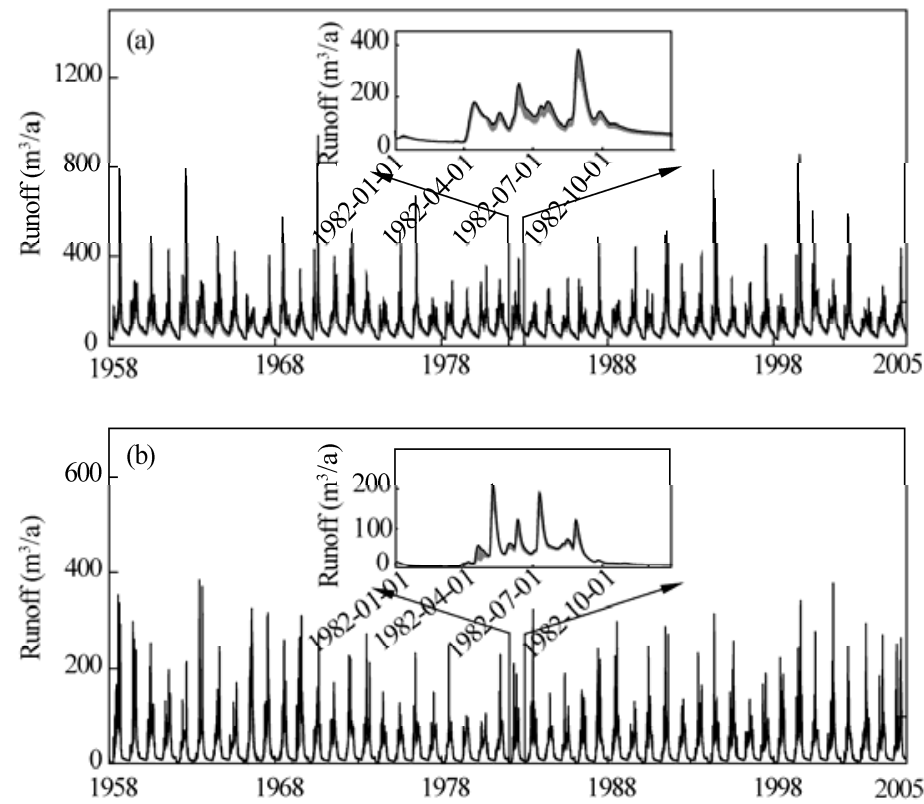

Fig. 3 Simulated runoff under different climatic disturbances in the Kaidu River watershed (a) and in the Manas River watershed (b). Small figures in (a) and (b) clearly show the influence of climatic disturbances on intra-annual runoff by magnifying the runoff within a year in 1982.

To quantitatively describe the impact of climatic disturbance on the annual distribution of runoff, we showed the sensitivity of annual and seasonal runoff to climatic disturbance in the Kaidu River and Manas River watersheds in Table 3. In the Kaidu River watershed, variation in annual runoff ranged from $-4.71 \%$ to 0 , and variation in seasonal runoff ranged from $-7.82 \%$ to $1.16 \%$ under the scenarios of $\mathrm{T}_{\mathrm{a}^{+}}, \mathrm{T}_{\mathrm{s}+}, \mathrm{T}_{\mathrm{ss}^{+}} \mathrm{T}_{\mathrm{aa}^{+}}$and $\mathrm{T}_{\mathrm{w}+}$. This finding indicated that annual and seasonal runoff was not sensitive to temperature disturbance. Scenarios where annual mean temperature increased by $2^{\circ} \mathrm{C}$ resulted in the decreases of annual and seasonal runoff, except for 
the spring runoff. Annual and seasonal runoff was more sensitive to annual precipitation increasing by $20 \%$, with values between $11.07 \%$ and $21.69 \%$. However, variation in solid precipitation had little influence on annual and seasonal runoff (less than 1.2\%). In the Manas River watershed, spring runoff was more sensitive to $\mathrm{T}_{\mathrm{a}^{+}}$and $\mathrm{T}_{\mathrm{s}^{+}}$, with values of $28.52 \%$ and $33.30 \%$, while annual and other seasonal runoff was not sensitive to annual and seasonal temperature increases $(-7.32 \%$ to $9.04 \%)$. The values of annual and seasonal runoff varied from $3.62 \%$ to $10.05 \%$, with an increase of $20 \%$ in annual precipitation. Under the scenario where solid precipitation increased by $20 \%$, annual and seasonal runoff changed from $0.06 \%$ to $0.70 \%$ in the watershed.

Table 3 Sensitivity (\%) of annual and seasonal runoff under different scenarios in the Kaidu River and Manas River watersheds

\begin{tabular}{ccccccccc}
\hline Watershed & & $\mathrm{T}_{\mathrm{a}+}$ & $\mathrm{T}_{\mathrm{s}+}$ & $\mathrm{T}_{\mathrm{ss}+}$ & $\mathrm{T}_{\mathrm{aa}+}$ & $\mathrm{T}_{\mathrm{w}+}$ & $\mathrm{P}_{\mathrm{a}^{+}}$ & $\mathrm{P}_{\mathrm{s}^{+}}$ \\
\hline \multirow{3}{*}{ Kaidu River } & Annual & -4.71 & -0.96 & -3.58 & 0.00 & -0.10 & 15.89 & 0.70 \\
watershed & Spring & -0.87 & 1.16 & -1.84 & -0.76 & 0.04 & 11.07 & 1.12 \\
& Summer & -7.82 & -2.48 & -5.19 & -0.63 & 0.04 & 21.69 & 0.40 \\
& Autumn & -4.91 & -1.24 & -3.96 & -0.12 & 0.04 & 17.96 & 0.81 \\
& Winter & -5.23 & -1.28 & -3.35 & -0.45 & -0.51 & 12.80 & 0.46 \\
& Annual & 7.40 & 9.04 & -3.83 & 2.64 & 0.99 & 6.58 & 0.33 \\
Manas River & Spring & 29.52 & 33.30 & 1.54 & 4.01 & 3.97 & 6.56 & 0.40 \\
watershed & Summer & -2.42 & -0.39 & -7.32 & -0.06 & -0.09 & 10.05 & 0.06 \\
& Autumn & 3.78 & 1.34 & -4.18 & 5.60 & 0.03 & 6.05 & 0.70 \\
& Winter & -1.47 & 1.69 & -5.39 & 1.01 & 0.04 & 3.62 & 0.17 \\
\hline
\end{tabular}

Note: $\mathrm{T}_{\mathrm{a}+}$, mean air temperature increases $2^{\circ} \mathrm{C}$ during the entire year; $\mathrm{T}_{\mathrm{s}^{+}}$, mean air temperature increases $2{ }^{\circ} \mathrm{C}$ in spring (March to May); $\mathrm{T}_{\mathrm{ss}+}$, summer (June to August); $\mathrm{T}_{\mathrm{aa}+}$, autumn (September to November); $\mathrm{T}_{\mathrm{w}+}$, winter (December to February); $\mathrm{P}_{\mathrm{a}+}$, precipitation increases $20 \%$ during the entire year; $\mathrm{P}_{\mathrm{s}^{+}}$, precipitation takes place as snowfall increases $20 \%$, while rainfall does not change.

The degree of runoff variation in the Kaidu River watershed was approximately 1.5 times greater than that in the Manas River watershed. On average, spring floods started on the $97^{\text {th }}$ day of year (DOY) in the Kaidu River watershed, but spring flow began to increase on the $131^{\text {th }}$ DOY, without an obvious spring peak in the Manas River watershed from the basic scenario. Under the $\mathrm{T}_{\mathrm{a}+}$ scenario, spring peak flow took place earlier, with a greater peak in both watersheds than that under basic scenario. The magnitude of summer peak was less than that under the basic scenario in the two watersheds. Under the $\mathrm{T}_{\mathrm{s}^{+}}$scenario, runoff increased from March to April and decreased from the end of April to May in the Kaidu River watershed. On the other hand, runoff increased from March to May in the Manas River watershed. Under the $T_{\text {ss }}$ scenario, runoff decreased from June to September relative to the basic scenario in the Kaidu River watershed, while runoff decreased from July to August in the Manas River watershed. Runoff changed little over the entire year under the scenarios of $\mathrm{T}_{\mathrm{aa}^{+}}$and $\mathrm{T}_{\mathrm{w}+}$. Under the $\mathrm{P}_{\mathrm{a}^{+}}$scenario, runoff was greater than that under the basic scenario throughout the year in both the Kaidu and Manas River watersheds, but its impact on runoff in the Kaidu River watershed is much greater than that in the Manas River watershed. Runoff under the $\mathrm{P}_{\mathrm{s}^{+}}$scenario was exceedingly similar to the runoff under the basic scenario in these two watersheds. The results indicated that the runoff on the southern slope of the MTM is more sensitive to the changes in precipitation, while runoff on the northern slope of the MTM is more sensitive to the temperature variation.

\section{Discussion}

\subsection{Runoff patterns in northern and southern slopes of the MTM}

Slopes in alpine Tianshan Mountains significantly influence annual runoff, including average annual runoff and intra-runoff pattern. The average annual runoff depth observed in the steep 
Manas River watershed $(2.80 \mathrm{~mm})$ is greater than that in the Kaidu River watershed $(2.16 \mathrm{~mm})$ (Li et al., 2012). In present study, two peaks flows in spring from March to May and in summer from June to August were well simulated in the Kaidu River watershed, and one peak flow in summer from June to August was regenerated in the Manas River watershed. The peaks simulated in both watersheds were consistent with the results of Ji and Luo (2013) and Zhang et al. (2016). The different distribution of intra-annual runoff on the northern and southern slopes of the MTM is determined by climatic factors, which are controlled by the slopes at which these two watersheds are located. Due to the influence of prevalent westerly circulation, precipitation in the northern slope is greater than that in the southern slope due to the obstruction of the MTM. Aizen et al. (1995) concluded that the MTM has maximum levels of precipitation in the summer and small levels of precipitation in the winter. More than $60 \%$ of the precipitation (in the form of rainfall) falls from June to August, while less than $10 \%$ of the precipitation (in the form of snowfall) falls from December to February in these two watersheds. The distributions of precipitation in these two watersheds are similar to that from Aizen et al. (1995). Temperature, as another key climatic factor, also has a great difference in both watersheds. The annual mean temperature in the upper stream of Kaidu River watershed was $-4.32^{\circ} \mathrm{C}$ (Huang, 2009), and that in the Manas River watershed was $6.6^{\circ} \mathrm{C}$ (Chen et al., 2006), which led to the different timing and intensity of snow/glacier melt as well as evapotranspiration in both watersheds. Therefore, the slopes in the MTM resulted in the difference in climatic factors, which influenced the proportion and relative contribution of different water sources to runoff in both watersheds.

Dodds (1997) also demonstrated that slope had a great impact on runoff after analyzing the relationship between runoff and slope using the global datasets. The impacts are possibly realized through watershed characteristics, such as the structure and patterns in vegetation (Armesto and Martínez, 1978; Badano et al., 2005), soil types (Kutiel, 1992), precipitation (Han et al., 2004; Yang et al., 2007) and proportions of both glacier-melt water (Li et al., 2012) and snowmelt water to runoff (Lan et al., 2011). The elevational range in the Kaidu River watershed was smaller (from 1,400 to $4,794 \mathrm{~m}$ asl) than that in the Manas River watershed (from 885 to $5,193 \mathrm{~m}$ asl), but the area above the mountain pass was much greater in the Kaidu River watershed $\left(18,725 \mathrm{~km}^{2}\right)$ than that in the Manas River watershed $\left(5,156 \mathrm{~km}^{2}\right)$, which shaped the different slope gradients and sub-catchment sizes in both watersheds. In the Kaidu River watershed, the area of the sub-catchment SMM was the largest, and the area of the sub-catchment RL was the second largest among the three sub-catchments. Large confluences of seasonal snowmelt water generated a spring peak during snowmelt period, while heavy rainfall in the summer generated a summer peak in the Kaidu River watershed, which resulted in two peaks within a year (Zhang et al., 2016). In the Manas River watershed, the area of the sub-catchment GMH was the largest and the area of the sub-catchment SMM was the second largest (Ji and Luo, 2013). The relative contribution of annual glacier-melt water to annual runoff in the Manas River watershed was two times greater than that in the Kaidu River watershed. A small confluence of seasonal snowmelt water, combined with a steep slope, weakened the contribution of snowmelt water to runoff. Hence, snowmelt water could not generate spring peak flow in the Manas River watershed. The contribution of glacier-melt water to runoff in the summer was higher compared to other seasons because glacier-melt processes were strongly linked to temperature variation. Glacier-melt water, combined with heavy rainfall in the summer, resulted in runoff with only one summer peak in the Manas River watershed.

\subsection{Response of runoff to climatic disturbance}

Temperature and precipitation variations substantially influence both annual and seasonal runoffs, but the responses of runoff to climatic variations differ in different watersheds (Lan et al., 2011; Li et al., 2012). Li et al. (2012) compared the impact of meteorological factors on runoff in both Kaidu River and Manas River watersheds using path analysis. The results demonstrated that the direct influence of temperature on runoff was more remarkable than that of precipitation in the Manas River watershed due to the critical impact of temperature on snow/glacier-melt, but the direct influence of temperature on runoff was not significant as that of precipitation in the Kaidu 
River watershed. After comparing the responses of runoff to climate change in the Kaidu River watershed and in the Urumqi River watershed using sensitivity analysis, Lan et al. (2011) concluded that runoff was more sensitive to temperature variation in the Kaidu River watershed in the southern slope of the MTM, but more sensitive to precipitation in the Urumqi River watershed on the northern slope of the MTM. However, this study demonstrated that runoff was more sensitive to temperature variation in the Manas River watershed and more sensitive to precipitation variation in the Kaidu River watershed. The results of this study were consistent with those of Li et al. (2012) but were inconsistent with those of Lan et al. (2011). Snow/glacier cover area determined by geophysical location and elevation is the primary reason to explain why runoff exhibits different sensitivities to different climatic variables in the Kaidu River watershed and in the Urumqi River watershed (Lan et al., 2011). The total glacier area $\left(102.2 \mathrm{~km}^{2}\right)$ accounts for approximately $2.18 \%$ of the Urumqi River watershed $\left(4,681 \mathrm{~km}^{2}\right.$ ) (Lan et al., 2011), and the glacier melt water accounts for $8 \%-10 \%$ of the total runoff under normal condition of the Urumqi River watershed (Wang et al., 2005; Wu et al., 2006). The proportion of glacier area and the glacier storage in the Urumqi River watershed are less than that in the Kaidu and Manas River watershed. The intra-annual precipitation has a one-peak pattern (Zhang et al., 2011) in the Urumqi River watershed, i.e. most precipitation happens from May to September. The proportion of glacier area, glacier storage and the intra-annual distribution of precipitation lead to runoff becoming more sensitive to precipitation than that to temperature in the Urumqi River watershed. Compared with the Urumqi River watershed, large conference area of seasonal snowmelt in the Kaidu River watershed leads to runoff becoming more sensitive to temperature than that to precipitation.

Li et al. (2012) demonstrated that daily accumulated temperature and precipitation had significant direct effects on daily runoff depth in all seasons, except for winter. Due to the existence in temperature variation from $<0^{\circ} \mathrm{C}$ to $>0{ }^{\circ} \mathrm{C}$ in spring, an increase in daily mean air temperature with $2^{\circ} \mathrm{C}$ leads to an earlier occurrence of temperature change from $<0^{\circ} \mathrm{C}$ to $>0{ }^{\circ} \mathrm{C}$, which could result in earlier and stronger spring peak flow and spring flow. The response of spring peak flow to temperature increases was consistent with the findings of Regonda et al. (2005), Stewart et al. (2005) and the National Research Council (2007). Spring runoff was more sensitive to temperature increases in the Manas River watershed than that in the Kaidu River watershed. The primary reason is that increased temperature cannot change the volume of snowmelt water, but it will increase the volume of glacier-melt water. The volume of snowmelt water depends on available snowpack stored during winter, while glacier-melt exists in the whole year in both watersheds. Glacier area and storage in the Manas River watershed are much greater than that in the Kaidu River watershed, which results in more glacier-melt water to charge runoff in the Manas River watershed when daily mean temperature increased in spring. The influence of temperature variation on runoff is also determined by evapotranspiration ( $\mathrm{Li}$ et al., 2015). Higher temperature increases evapotranspiration (Wang et al., 2011). Temperature in summer is higher than that in other seasons; therefore, evapotranspiration in summer is more sensitive to temperature variation. Temperature in autumn was lower than that in the summer-even when temperature increases by $2^{\circ} \mathrm{C}$. Winter temperature in both watersheds is far below $0^{\circ} \mathrm{C}$, which makes the melting point of snow impossible to reach, even when temperature increases by $2^{\circ} \mathrm{C}$. Hence, temperature will influence the summer and autumn runoff through changing the evapotranspiration. The results of runoff sensitivity to temperature variation in this study were similar to those of Li et al. (2012). Precipitation in the form of rainfall is a direct source of runoff that has a tremendous influence on runoff annually and during rainfall seasons. On the other hand, precipitation in the form of snowfall cannot charge runoff immediately due to delays in snowmelt (Martinec, 1975) and therefore has little influence on runoff in winter. Summer precipitation accounts for more than $60 \%$ of annual precipitation. Summer runoff increases more significantly than that in other seasons when precipitation increases by $20 \%$. The proportion of precipitation that falls from October to February as snowfall only accounts for $7 \%$ and $17 \%$ of the total precipitation in the Kaidu River watershed and in the Manas River watershed, respectively. The influence of precipitation variation on runoff is consistent with the findings of Li et al. (2012). 


\section{Conclusions}

The modified SDHydro model can efficiently simulate runoff in watersheds on the northern and southern slopes of the MTM. The results of this study revealed that runoff was more sensitive to precipitation variation on the southern slope and more sensitive to temperature variation on the northern slope, after evaluating the sensitivity of runoff to different types of climatic disturbance. The increase of spring runoff occurred earlier on the southern slope than that on the northern slope. Increasing temperature resulted in an earlier, larger increase in spring flow but decreased summer peak flow in both watersheds. Variation in patterns of intra-annual runoff on the northern and southern slopes of the MTM will provide more useful information for water managers to effectively allocate and manage water resources in the future.

\section{Acknowledgements}

This work was funded by the National Basic Research Program of China (2012CB956204), the Special Funds for the Key Laboratory of the Xinjiang Uygur Autonomous Region (2014KL015) and the Key Deployment Project of Chinese Academy of Sciences (KZZD-EW-12-2).

\section{References}

Aizen V B, Aizen E M, Melack J M. 1995. Climate, snow cover, glaciers, and runoff in the Tien Shan, central Asia. Journal of the American Water Resources Association, 31(6): 1113-1129.

Armesto J J, Martínez J A. 1978. Relations between vegetation structure and slope aspect in the Mediterranean region of Chile. Journal of Ecology, 66(3): 881-889.

Badano E I, Cavieres L A, Molina-Montenegro M A, et al. 2005. Slope aspect influences plant association patterns in the Mediterranean matorral of central Chile. Journal of Arid Environments, 62(1): 93-108.

Chen G W M, Zhou C H, Liu H J, et al. 2006. The oasis expansion and eco-environment change over the last 50 years in Manas River Valley, Xinjiang. Science in China: Series D, 49(2): 163-175.

Chen X, Liang S, Bao A. 2014. Application of Snowmelt Runoff Model (SRM) in ungagged Manasi River Basin, Northwest China. In: AGU Fall Meeting Abstracts. Washington, DC: American Geophysical Union.

Dodds W K. 1997. Distribution of runoff and rivers related to vegetative characteristics, latitude, and slope: A global perspective. Journal of the North American Benthological Society, 16(1): 162-168.

Dou Y. 2010. Climate change impact on snowcover and runoff in the Tianshan Mountains. PhD Dissertation. Beijing: University of Chinese Academy of Sciences. (in Chinese)

Dou Y, Chen X, Bao A M, et al. 2011. The simulation of snowmelt runoff in the ungauged Kaidu River Basin of Tianshan Mountains, China. Environmental Earth Sciences, 62(5): 1039-1045.

Fan Y T, Chen Y N, Liu Y B, et al. 2013. Variation of baseflows in the headstreams of the Tarim River Basin during 1960-2007. Journal of Hydrology, 487: 98-108.

Han T D, Ding Y J, Ye B S, et al. 2004. Precipitation variations on the southern and northern slopes of the Tianger range in Tianshan Mountains. Journal of Glaciology and Geocryology, 26(6): 761-766. (in Chinese)

Hu R J. 2004. Physical Geography of the Tianshan Mountains in China. Beijing: China Environmental Science Press. (in Chinese)

Huang Y. 2009. Distributed hydraulic modeling in arid ungauged basin. PhD Dissertation. Urumqi: Xinjiang Institue of Ecology and Geography, Chinese Academy of Sciences. (in Chinese)

Ji X, Luo Y. 2013. The influence of precipitation and temperature input schemes on hydrological simulations of a snow and glacier melt dominated basin in Northwest China. Hydrology and Earth System Sciences Discussions, 10(1): 807-853.

Kalra A, Ahmad S, Nayak A, et al. 2013. Increasing streamflow forecast lead time for snowmelt driven catchment based on large-scale climate patterns. Advances in Water Resources, 53: 150-162.

Kutiel P. 1992. Slope aspect effect on soil and vegetation in a Mediterranean ecosystem. Israel Journal of Botany, 41(4-6): 243-250.

Kuusisto E. 1984. Snow accumulation and snowmelt in Finland. Finland: Publications of the Water Research Institute, National Board of Waters.

Lan Y C, Zhong Y J, Wu S F, et al. 2011. Response of mountain runoff to climate change in representative rivers originated from the Tianshan Mountain. Journal of Desert Research, 31(1): 254-260. (in Chinese) 
Li L, Simonovic S P. 2002. System dynamics model for predicting floods from snowmelt in North American prairie watersheds. Hydrological Processes, 16(13): 2645-2666.

Li L H, Shang M, Zhang M S, et al. 2014. Snowmelt runoff simulation driven by APHRODITE precipitation dataset. Advances in Water Science, 25(1): 53-59. (in Chinese)

Li Q, Li L H, Bao A M. 2012a. Snow cover change and impact on streamflow in the Kaidu river basin. Resources Science, 34(1): 91-97. (in Chinese)

Li S S, Zhang F Y, Bai L, et al. 2015. Spatiotemporal variation and sensitivity of reference crop evapotranspiration during growth season in northern Xinjiang. Chinese Journal of Agrometeorology, 36(6): 683-691. (in Chinese)

Li X M, Zhang F Y, Shang M, et al. 2012b. Path analysis on impacts of meteorological factors on runoff from Tianshan Mountains: a case study on Manas River and Kaidu River watersheds. Resources Science, 34(4): 652-659. (in Chinese).

Li Y A, Tan Y, Jiang F Q, et al. 2003. Study on Hydrological features of the Kaidu River and the Bosten Lake in the second half of $20^{\text {th }}$ century. Journal of Glaciology and Geocryology, 25(2): 215-218. (in Chinese)

Li Z, Liu W Z, Zhang X C, et al. 2009. Impacts of land use change and climate variability on hydrology in an agricultural catchment on the Loess Plateau of China. Journal of Hydrology, 377(1-2): 35-42.

Liu C H. 1995. Glacier resources and distributive characteristics in the Central Asia Tianshan Mountains. Journal of Glaciology and Geocryology, 17(3): 193-203. (in Chinese)

Liu H L, Wang L, Bao A M, et al. 2009. Analysis on snow and ice cover area in Manasi River basin based on Modis data. Journal of Shihezi University: Natural Science, 27(6): 770-773. (in Chinese)

Liu X K, Rao Z G, Zhang X J, et al. 2015. Variations in the oxygen isotopic composition of precipitation in the Tianshan Mountains region and their significance for the Westerly circulation. Journal of Geographical Sciences, 25(7): 801-816.

Ma H, Cheng G D. 2003. A test of Snowmelt Runoff Model (SRM) for the Gongnaisi River basin in the western Tianshan Mountains, China. Chinese Science Bulletin, 48(20): 2253-2259.

Martinec J. 1975. Snowmelt-runoff model for stream flow forecasts. Hydrology Research, 6(3): 145-154.

Moriasi D N, Arnold J G, Van Liew M W, et al. 2007. Model evaluation guidelines for systematic quantification of accuracy in watershed simulations. Transactions of the ASABE, 50(3): 885-900.

Mu W F. 1991. A review on the supply of water vapour to heavy rain process in arid regions of China. Quarterly Journal of Applied Meteorology, 2(3): 308-314.

National Research Council. 2007. Colorado River Basin Water Management: Evaluating and Adjusting to Hydroclimatic Variability. Washington, DC: National Academics Press.

Ran S H, Li X B, Lv C H. 2006. Multi-scale modeling of land-cover change and ecosystem service values: a case of the Yuzixi catchment in Sichuan. Acta Geographica Sinica, 61(10): 1113-1120. (in Chinese)

Regonda S K, Rajagopalan B, Clark M, et al. 2005. Seasonal cycle shifts in hydroclimatology over the western United States. Journal of Climate, 18(2): 372-384.

Shang M, Li L H, Yao Y N, et al. 2013. Analysis of factors affecting peak flow of the Kaidu River on the southern slope of the Tianshan Mountains. Journal of Arid Land Resources and Environment, 27(9): 85-91. (in Chinese)

Shi Y F, Shen Y P, Kang E S, et al. 2007. Recent and future climate change in northwest China. Climatic Change, 80(3-4): 379-393.

Shi Y G. 2014. Spatial-temporal Distribtion and Change of Precipitation and Vapor in Xinjiang. Beijing: China Meteorological Press. (in Chinese)

Stewart I T, Cayan D R, Dettinger M D. 2005. Changes toward earlier streamflow timing across western North America. Journal of Climate, 18(8): 1136-1155.

Su H C, Shen Y P, Han P, et al. 2007. Precipitation and its impact on water resources and ecological environment in Xinjiang region. Journal of Glaciology and Geocryology, 29(3): 343-350. (in Chinese)

Sun M P, Yao X J, Li Z Q, et al. 2015. Hydrological processes of glacier and snow melting and runoff in the Urumqi River source region, eastern Tianshan Mountains, China. Journal of Geographical Sciences, 25(2): 149-164.

Vincent L A, Gullett D W. 1999. Canadian historical and homogeneous temperature datasets for climate change analyses. International Journal of Climatology, 19(12): 1375-1388.

Wang G Q, Zhang J Y, Liu J F, et al. 2011. The sensitivity of runoff to climate change in different climatic regions in China. Advances in Water Science, 22(3): 307-314. (in Chinese)

Wang G Y, Shen Y P, Mao W Y. 2005. Climate warming at headwater of Ürümqi River, Xinjiang in past 44 years and its impact on glacier shrinking. Journal of Glaciology and Geocryology, 27(6): 813-819. (in Chinese)

Wu S F, Liu Z H, Han P, et al. 2006. Impact of climate change on water resources of the Urumqi River Basin. Journal of Glaciology and Geocryology, 28(5): 703-706. (in Chinese) 
Xu J H, Chen Y N, Ji M H, et al. 2008. Climate change and its effects on runoff of Kaidu River, Xinjiang, China: A multiple time-scale analysis. Chinese Geographical Science, 18(4): 331-339.

Yang M, Ye B S, Peng P H, et al. 2012. A simulation of glacial runoff at headwaters of the Urumqi River. Journal of Glaciology and Geocryology, 34(1): 130-138. (in Chinese)

Yang M X, Yao T D, Gou X H, et al. 2007. Comparison analysis of the summer monsoon precipitation between northern and southern slopes of Tanggula Mountains, Qinghai-Xizang (Tibetan) Plateau: a case study in summer 1998. Hydrological Processes, 21(14): 1841-1847.

Yang Q, Cui C X. 2005. Impact of climate change on the surface water of Kaidu River Basin. Journal of Geographical Sciences, 15(1): 20-28.

Yu M Y, Chen X, Li L H, et al. 2011. Streamflow simulation by SWAT using different precipitation sources in large arid basins with scarce rain gauges. Water Resources Management, 25(11): 2669-2681.

Yu M Y, Chen X, Li L H, et al. 2013. Incorporating accumulated temperature and algorithm of snow cover calculation into the snowmelt runoff model. Hydrological Processes, 27(25): 3589-3595.

Zhang F Y, Li L H, Ahmad S, et al. 2014. Using path analysis to identify the influence of climatic factors on spring peak flow dominated by snowmelt in an alpine watershed. Journal of Mountain Science, 11(4): 990-1000.

Zhang F Y, Ahmad S, Zhang H Q, et al. 2016. Simulating low and high streamflow driven by snowmelt in an insufficiently gauged alpine basin. Stochastic Environmental Research and Risk Assessment, 30(1): 59-75.

Zhang P, Wang J, Liu Y, et al. 2009. Application of SRM to flood forecast and for warning of Manasi River Basin in Spring. Remote Sensing Technology and Application, 24(4): 456-461. (in Chinese)

Zhang S Q, Pu Z C, Wang S L. 2011. Spatio-temporal change characteristics of precipitation in Urumqi River Basin. Journal of Xinjiang Agricultural University, 34(1): 66-70. (in Chinese)

Zhang Y C, Li B L, Bao A M, et al. 2007. Study on snowmelt runoff simulation in the Kaidu River basin. Science in China Series D: Earth Sciences, 50(Suppl.): 26-35.

Zhao C C, Ding Y J, Ye B S, et al. 2011. Spatial distribution of precipitation in Tianshan Mountains and its estimation. Advances in Water Science, 22(3): 315-322. (in Chinese) 